\title{
Health risk assessment of potentially toxic elements via consumption of vegetables irrigated with polluted river water in Addis Ababa, Ethiopia
}

\author{
Minbale Aschale ${ }^{1,2^{*}}$, Yilma Sileshi ${ }^{3}$ and Mary Kelly-Quinn ${ }^{4}$
}

\begin{abstract}
Background: Vegetables grown at contaminated sites can take up and accumulate toxic and potentially toxic elements at concentrations that are toxic to human health. The present study determined the levels of potentially toxic elements/PTEs in irrigation water, soil and vegetable samples grown along contaminated river and assessed the potential health risks to consumers.

Results: The average concentrations of $\mathrm{Mn}, \mathrm{Sr}$ and $\mathrm{Cr}$ in the irrigation water were higher than the international guideline values. The levels of $\mathrm{As}, \mathrm{Cr}, \mathrm{B}$ and $\mathrm{Ni}$ in most of the farm soils were also found to be higher than the guideline values. Other PTEs, although not exceeding the recommended limits were relatively high in the soil and water samples. The study also revealed that the mean levels of $\mathrm{Cr}$, $\mathrm{Cd}$ and $\mathrm{Fe}$ in most vegetables were higher than the maximum recommended limits. Swiss chard was maximally contaminated with PTEs followed by lettuce, cabbage, Ethiopian kale, carrot and potato. Hence, frequent consumption of lettuce and Swiss chard may cause serious health risks to consumers.
\end{abstract}

Conclusion: The levels of many elements were varied with location, suggesting localized inputs of the various contaminants related to industrial and other activities that generate wastewater.

Keywords: Pollution, Irrigation water, Soil, Vegetable, Potentially toxic elements (PTEs), Risk index

\section{Background}

Vegetables grown at contaminated sites can take up and accumulate toxic and potentially toxic elements (PTEs) (e.g. arsenic, lead and cadmium) at concentrations that are toxic to human health and living organisms (Khan et al. 2008; Agrawal and Marshall 2009). The accumulation of such PTEs is greatly influenced by the concentration of pollutant in soil, its chemical species and the physico-chemical properties of the soil as well as the vegetable's growth distinctiveness (Dudka and Chlopecka 1990). Frequent application of polluted irrigation water could strongly influence the speciation of PTEs, decrease

\footnotetext{
*Correspondence: minsinas@yahoo.com

${ }^{1}$ College of Natural and Computational Sciences, Haramaya University, Dire Dawa, Ethiopia

Full list of author information is available at the end of the article
}

the soil sorption ability and hence, the PTEs are finally leached into the soil solution making them more available for vegetable uptake (Sridhara et al. 2008). The accumulation of PTEs in the edible parts of vegetables with high concentrations could have a direct impact on the health of consumers. The bioavailability, toxicity, and reactivity of many PTEs such as As and $\mathrm{Cr}$ depend on their chemical speciation (Pandey and Madhuri 2014a, b). PTEs are non-degradable, long biological half-life, less visible, not metabolized and can accumulate in the human body. On acute and chronic exposure, they cause damage to the nervous system, dysfunction of kidney, liver, lung, bladder prevalence cancer, high blood pressure, skin disorders and reproductive system (Lee et al. 2007; Kar et al. 2008; Lohani et al. 2008). Prolonged and frequent human consumption of vegetable contaminated by PTEs 
such arsenic (As), lead $(\mathrm{Pb})$, cadmium $(\mathrm{Cd})$, nickel $(\mathrm{Ni})$ and strontium (Sr), even at low levels, presents potential human health risks.

Urban agriculture, mainly to produce vegetables and crops, has a significant place in the city of Addis Ababa. Addis Ababa with approximately 5 million people is a prominent industrial hub and one of the fastest growing cities in Ethiopia. The old as well as new industrial effluents, public and domestic utilities in the city release untreated wastes into nearby rivers and streams. More than 160 hectares of agricultural land are annually used to grow crops and vegetables. The source of irrigation water is untreated streams and rivers. Irrigation is performed either by direct flooding the roots of the crops after diverting the river or using water motor pumping. These wastewaters could pollute the soil with PTEs and hence the vegetables and crops grown on these soils could be a potential health concern to consumers.

Currently, in Ethiopia there is no regulatory criterion of PTEs in irrigation water, soils and vegetables. However, due to businesses economic, industrial and other development activities, the levels of PTEs are increasing in the irrigation water, agricultural soils, vegetables and crops grown in and outside the city. Itanna (1998) determined PTEs in leafy vegetables grown in Addis Ababa and toxicological implications at Kera and Bulbula farms, and found that the levels of $\mathrm{Pb}$ and $\mathrm{Cr}$ at Kera farm, $\mathrm{Ni}$ and $\mathrm{Mn}$ at Kera and Bulbula farms, $\mathrm{Zn}$ at Bulbula farm were generally higher in soils because of the disposal of industrial and domestic wastes (Ewers 1991; Pendias and Pendias 1992). Weldegebriel et al. (2012) studied the levels of $\mathrm{Pb}, \mathrm{Cd}, \mathrm{Ni}, \mathrm{Cr}, \mathrm{Co}, \mathrm{Mn}, \mathrm{Zn}$ and $\mathrm{Cu}$ at Goffa, Akaki, Peacock and Kera vegetable farms and the results showed that most of the levels of PTEs were higher than the background values for uncontaminated soils due to human activities. Even if the farmlands and along the bank of the river areas are extensively used in crops and vegetables production in the city, still very little information exists regarding the levels of PTEs in irrigation water, soils and vegetables. Therefore, the aim of this work was to determine the levels of PTEs in irrigation water, soil and vegetable samples grown along the river and its main tributaries. Multivariate statistical analysis would be employed to identify the common sources and assess the potential health risks to consumers. The results will provide invaluable baseline data for further investigation of PTEs accumulation in food stuffs, thereby improving food safety and the health of its inhabitants.

\section{Materials and methods}

\section{Sample collection and analysis}

As shown in Fig. 1 samples were collected from Addis Ababa, Ethiopia. It is geographically located at $9^{\circ} \mathrm{N}$ and $38^{\circ} \mathrm{E}$ between 2200 and $2500 \mathrm{~m}$ above sea level. The two major rivers in the city are the Little Akaki River with a catchment area of about $540 \mathrm{~km}^{2}$, which flows through the western part of the city and Big Akaki River and a catchment area of about $900 \mathrm{~km}^{2}$, which flows through the eastern part of the city (Fig. 1). Most of the industries are located along the course of the Little Akaki River and its tributaries. These include leather/tanneries, textiles, battery and paints, wood works, food and beverages, pharmaceutical, non-metal and metal products, wineries, rubber and plastic products, paper and printing. The industrial wastewaters are discharged into the small river network, most often untreated. At the same time the river is used for irrigation to produce different vegetables such as swiss chard, lettuce, potato, cabbage, carrot and onion. The five vegetable farms, namely Burayu, Kolfea, Kera, Gofa and Akaki are irrigated with water from the Little Akaki River and its tributaries (Fig. 1).

A total of 19 composite samples of vegetables; namely carrot (Daucus carota L.), Swiss chard (Beta vulgaris L. var. cicla), cabbage (Brassica oleracea L. var. capitata), lettuce (Lactuca sativa L.), Ethiopian kale (Brassica carinata A. Br.) and potato (Solanum tuberosum L.) were collected randomly from a minimum of twentyfive vegetables per sample from the five agricultural farms depending on their availability. During the same period, soil samples (ten to twenty samples) were collected randomly from distributed sampling points within the farms using a stainless steel auger $(0-20 \mathrm{~cm}$ depth). $500 \mathrm{~mL}$ of water samples were also collected at five sampling sites from diversion points of irrigation using cleaned polyethylene bottles.

The vegetable samples were cut into small pieces using a stainless steel knife after thoroughly washing with tap water and finally with deionized water. They were air dried, ground and homogenized using a pestle and mortar, and then preserved in polyethylene bags in a desiccator. Vegetable and soil samples were digested fully according to the USEPA 3050B acid digestion method using the mixture of $\mathrm{HNO}_{3}$ and $\mathrm{H}_{2} \mathrm{O}_{2}$ (Hagedorn 2008; Dowdell and Thompson 2014). Then each sample was analyzed in triplicate and the concentrations were determined as the average of replicates. The resulting mixture was finally analyzed by inductively coupled plasma mass spectrometry (ICP-MS) for the cadmium (Cd), arsenic (As), nickel (Ni), chromium $(\mathrm{Cr})$, strontium $(\mathrm{Sr})$, zinc $(\mathrm{Zn})$, manganese $(\mathrm{Mn})$, copper $(\mathrm{Cu})$, barium $(\mathrm{Ba})$, iron $(\mathrm{Fe})$, vanadium $(\mathrm{V})$, cobalt (Co) and boron (B) contents in the laboratory of the Inland Fisheries Ireland in Dublin, Ireland (Additional file 1). 


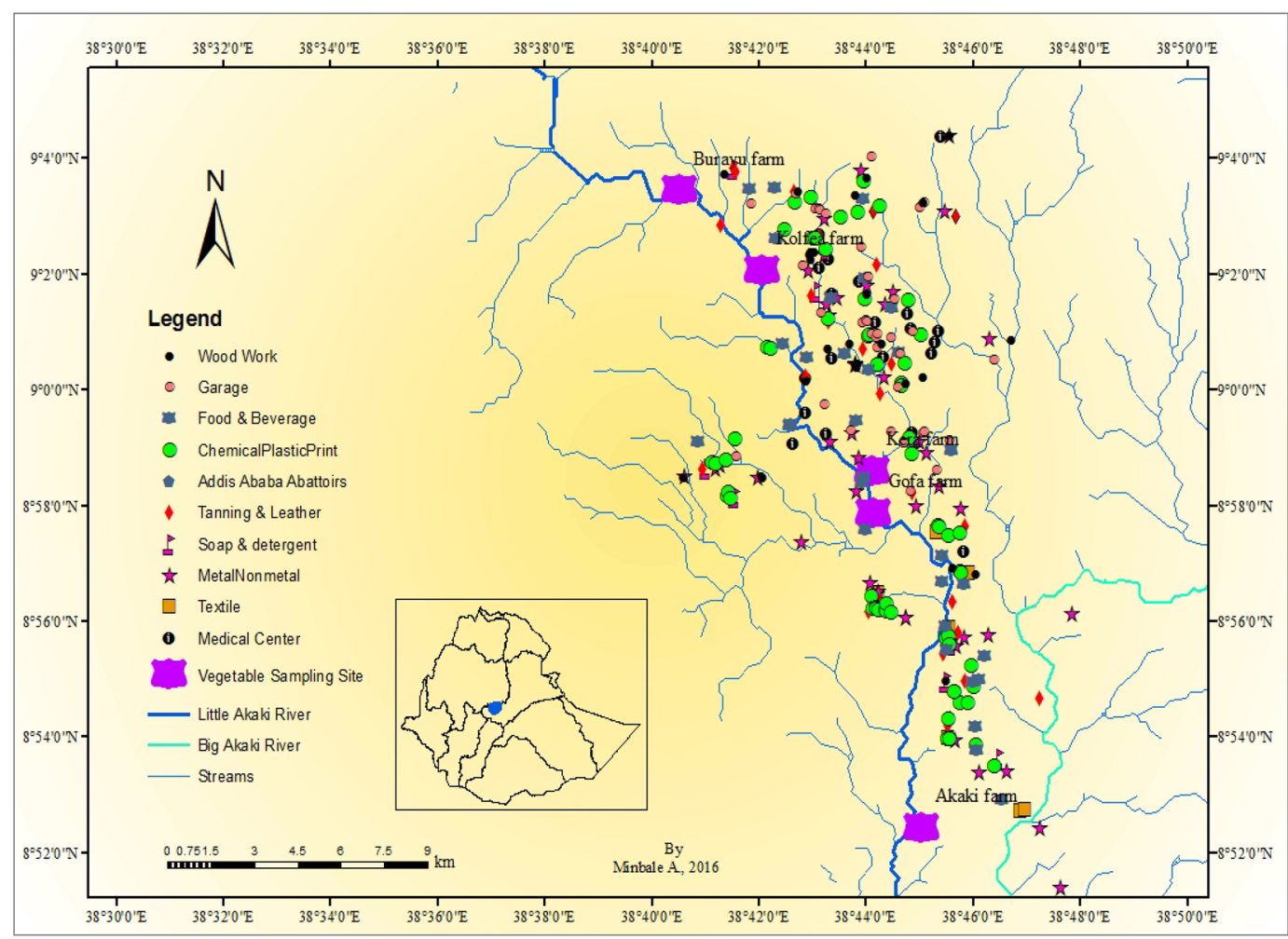

Fig. 1 Sampling sites of the study area in Addis Ababa

\section{Quality control and quality assurance}

For the validation of digestion procedure and ICP-MS instrument operation conditions, standard reference materials were included in every batch of sample analysis. Procedural blanks were included in each batch of samples. All of the analyses were duplicated to ensure the representativeness of the quantitative results. Calibration curves were regularly performed to evaluate the performances of the analytical methods and instruments. Certified reference materials, spinach leaves SRM 1570a for vegetable and San Joaquin soil SRM 2709a for soil obtained from the National Institute of Standards and Technology (Gaithersburg, MD, USA) were used to test the accuracy of the metal analysis. The percentage recoveries of the PTEs in the standard materials with known concentrations ranged from $78.88 \%$ to $119.6 \%$, indicating satisfactory recovery. The sample solutions, standard solutions, wash solutions and quality control standard solutions were made in a $0.5 \% \mathrm{HNO}_{3}$. All polyethylene bottles were washed with detergent, followed by repeated rinsing with distilled water and soaked overnight in $10 \% \mathrm{HNO}_{3}$ for $24 \mathrm{~h}$ and finally rinsed three times with doubly deionized water. Until collection, dried sample containers were kept in sealed polyethylene bags.
Data analysis of vegetable consumption-associated health risk assessment

\section{Bio-concentration factors (BCF)}

$\mathrm{BCF}$ is an index of the ability of a vegetable to accumulate a particular PTE as a function of its concentration in the agricultural soil (Cui et al. 2004; Khan 2013) and was calculated as follows:

$$
\mathrm{BCF}=\mathrm{C}_{\text {vegetable }} / \mathrm{C}_{\text {soil }}
$$

where $\mathrm{C}_{\text {vegetable }}$ is the total concentration of a particular PTE in the vegetable $(\mathrm{mg} / \mathrm{kg})$, and $\mathrm{C}_{\text {soil }}$ is the corresponding PTE concentration in the soil habitat of the vegetable $(\mathrm{mg} / \mathrm{kg})$. The higher the value of BCF, the more available the PTEs. Hence, the high BCF values may indicate potential risk to consumers.

\section{Daily intake of potentially toxic elements (DIM)}

The daily intake of PTEs was calculated to estimate the average daily PTE loading into the body system of a specified body weight of a consumer. The daily estimation through the consumption of vegetables depends on element concentrations in vegetables, the amount of daily vegetable consumption and body weight which 
was calculated according to the equation (Cui et al. 2004; Chary et al. 2008; Khan 2013):

$$
\mathrm{DIM}=\left(\mathrm{C}_{\text {metal }} \times \mathrm{D}_{\text {vegetable intake }}\right) / \mathrm{BW}_{\text {average weight }}
$$

where $C_{\text {metal }}=$ mean element concentration in vegetable $(\mathrm{mg} / \mathrm{kg})$ and $\mathrm{D}_{\text {vegetable }}=$ daily vegetable consumption/ intake $(\mathrm{kg} /$ day-person) and $\mathrm{BW}=$ average body weight $(\mathrm{kg})$. The average daily vegetable intake for adults and children was considered to be 0.345 and $0.232 \mathrm{~kg} /$ (person-day), respectively, while the average adults and children body weights was considered to be 55.9 and $32.7 \mathrm{~kg}$, respectively (Ge et al. 1996; Wang et al. 2005; Khan 2013).

\section{Hazard quotient (HQ)}

The HQ for the consumers through the consumption of contaminated vegetables was derived as the ratio of daily intake of PTE to the oral reference dose for each element using Eq. 3 (USEPA 1993, 2002; Chary et al. 2008). If the value of the hazardous quotient is less than 1 , then the exposed consumers are assumed to be safe, if the hazardous quotient is equal to or higher than 1 , and is considered as a level of concern or not safe for human health (USEPA 2002, 2013).

$$
\mathrm{HQ}=\left(\mathrm{C}_{\text {metal }} \times \mathrm{D}_{\text {vegetable intake }}\right) /\left(\mathrm{BW}_{\text {average weight }} \times \mathrm{R}_{\mathrm{f}} \mathrm{D}\right)
$$

The oral reference dose $\left(\mathrm{R}_{\mathrm{f}} \mathrm{D}\right)$ is an estimate of a daily oral exposure for the human population, which does not cause deleterious effects during a lifetime, generally used in USEPA's non-cancer health assessments (USEPA 2008). The $\mathrm{R}_{\mathrm{f}} \mathrm{D}$ values for $\mathrm{Cd}, \mathrm{Ni}, \mathrm{Mn}, \mathrm{Fe}, \mathrm{Cu}, \mathrm{Zn}, \mathrm{As}, \mathrm{Sr}, \mathrm{Ba}, \mathrm{B}$ and $\mathrm{Cr}$ are $0.001,0.02,0.14,0.7,0.04,0.3,0.0003,0.6,0.2,0.2$ and $1.5 \mathrm{mg} / \mathrm{kg}$-day, respectively, these were taken from Integrated Risk Information System (USEPA 1997, 1998, 2002, 2004, 2005, 2008). The value of $\mathrm{R}_{\mathrm{f}} \mathrm{D}$ for $\mathrm{V}$ (1.8 mg/kg-day) was taken from WHO (2004). There is no consensus about the $\mathrm{R}_{\mathrm{f}} \mathrm{D}$ for $\mathrm{Co}$, the oral reference dose for Co was taken as $0.043 \mathrm{mg} / \mathrm{kg}$-day from Food and Nutritional Board (2004).

\section{Hazard index (HI)}

Hazard index has been developed to evaluate the potential health risk to consumer through more than one PTE (USEPA 1998). It assumes that the magnitude of the adverse effect will be proportional to the sum of multiple metal exposures and linearly affect the target organ. It was calculated by summation of hazard quotients of all elements for each vegetable as follows (USEPA 1998; Jolly et al. 2013a, b, c; Geetanjali and Chauhan 2014).

$$
\begin{aligned}
\mathrm{HI}= & \sum \mathrm{HQ}=\mathrm{HQCr}+\mathrm{HQMn}+\mathrm{HQFe}+\mathrm{HQCu} \\
& +\mathrm{HQZn}+\mathrm{HQSr}+\mathrm{HQCd} \\
& +\mathrm{HQBa}+\mathrm{HQB}+\mathrm{HQV}+\mathrm{HQCo}+\mathrm{HQNi}
\end{aligned}
$$

\section{Statistical analysis}

Analysis of variance (ANOVA) was applied to assess significant differences in PTE concentrations at the various sampling sites. The homogeneity of variance and normal distribution of PTEs in sample stations were tested by using Levene statistic and the Shapiro-Wilk methods, respectively. Multivariate analysis of the element concentration dataset was performed through principal component analysis (PCA) and cluster analysis (CA) techniques.

\section{Results and discussion}

\section{Levels of PTEs in irrigation water, soil and vegetables}

The PTEs concentrations found in the agricultural soil and irrigation water samples analyzed and comparisons with the guideline values are presented in Table 1 . Those investigated are of increasing concern due to food safety issues and potential health risks, as well as pollution of nearby rivers and streams (Weldegebriel et al. 2012). The PTE concentration varied according to the sampling location of the study areas. The higher concentrations of $\mathrm{Mn}, \mathrm{As}, \mathrm{Ba}, \mathrm{Cd}$, $\mathrm{Pb}$ and $\mathrm{Zn}$ found in Kera soil could likely due to the influence of industrial wastes such as Kera Abattoir, municipal wastes and domestic wastes that joining the Kera stream. Most of the industries are established along the course of the Little Akaki River and its major tributaries. These include tanneries, breweries, wineries, distilleries, pharmaceutical and national alcohol liquor factories.

The concentrations of $\mathrm{Mn}, \mathrm{As}, \mathrm{Ba}, \mathrm{Cd}, \mathrm{Zn}$ and $\mathrm{Pb}$ were relatively higher in the river water samples analyzed at the same agricultural sampling site. These showed that the influence of irrigation water on the elemental levels of the agricultural soil of the study areas. Among the elements, the concentrations of $\mathrm{Cr}$ and $\mathrm{B}$ in Kolfea, $\mathrm{Mn}$ in Kera, Kolfea and Akaki farms were higher than the maximum concentration limits given for irrigation waters (Ayers and Westcot 1994). Previous reports also revealed that mean concentration of $\mathrm{Cd}, \mathrm{Co}$ and $\mathrm{Cu}$ in Akaki, $\mathrm{Mn}$ in $\mathrm{Gofa}, \mathrm{Cd}, \mathrm{Co}, \mathrm{Cu}, \mathrm{Mn}$ and of $\mathrm{Zn}$ in Kera farms (Weldegebriel et al. 2012); $\mathrm{Cu}$ and $\mathrm{Mn}$ in Kera River (Itanna 1998) were beyond the maximum concentration limits given for irrigation waters. The presence of high amounts of these PTEs in irrigation waters may increase their concentration in soils, which in turn may increase metal uptake by plants ultimately leading to elevated concentrations in the vegetables. The possible sources of pollution for potentially harmful elements in the river waters of the study areas may come from industrial effluents, direct solid or liquid waste deposal and urban emissions.

The average PTE concentrations of the soils in Kolfea farm for $\mathrm{Cr}$ and $\mathrm{Ni}$ were found to be higher than the maximum values of relevant guidelines (Ewers 1991; Pendias and Pendias 1992). Cr concentrations in all farms were also higher than $11 \mathrm{mg} / \mathrm{kg}$ of the standard limit set 


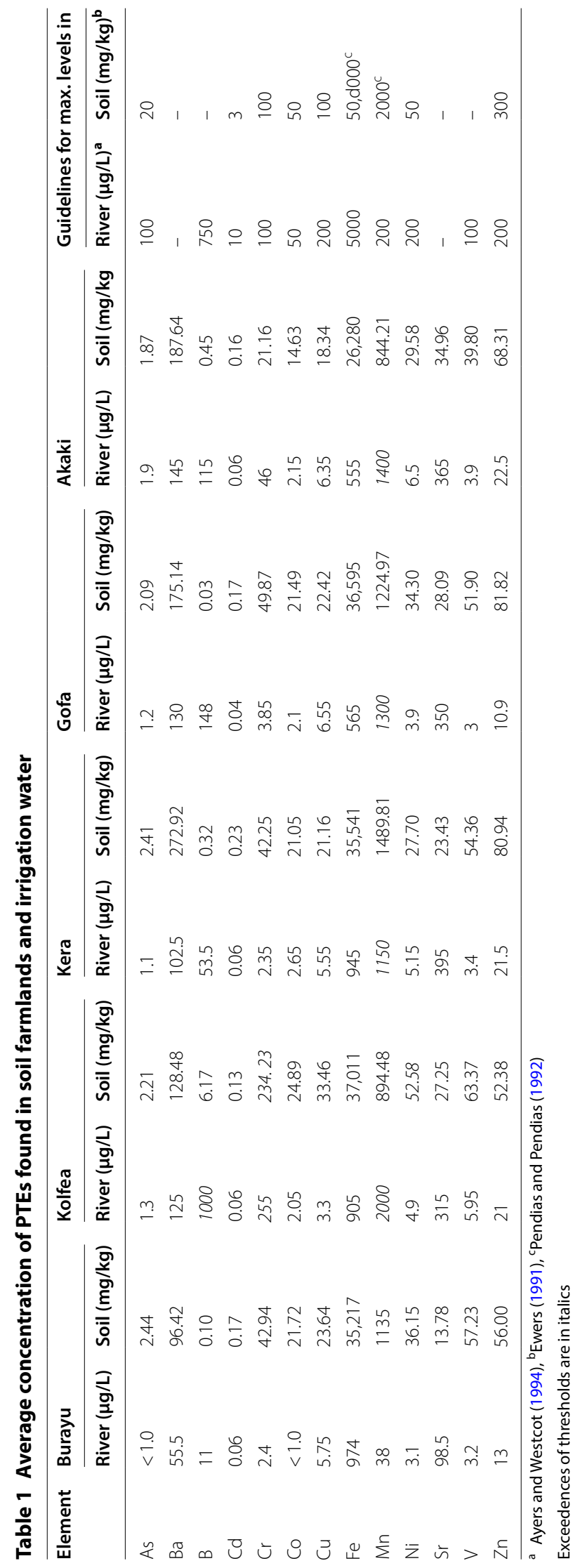


by the USEPA (2002). As shown in Table 1, the average result of $\mathrm{Ba}$ was lower than $500 \mathrm{mg} / \mathrm{kg}$ of the standard limit (CCME 2007). The concentration of B in Kolfea farm was higher than $2 \mathrm{mg} / \mathrm{kg}$ given on soil guidelines (CCME 2007). The concentrations of As in the soil samples studied were found to be higher than $0.11 \mathrm{mg} / \mathrm{kg}$ of the standard limit set by the USEPA (2002). Cd, Co, Ni and $\mathrm{Mn}$ concentrations in the agricultural soils were found to be higher than the average background soil concentrations given for uncontaminated soils (CEPA 1995), but the levels of $\mathrm{Fe}, \mathrm{Co}, \mathrm{Pb}, \mathrm{Cd}, \mathrm{Zn}, \mathrm{Mn}, \mathrm{V}$ and $\mathrm{Cu}$ were lower than the maximum permissible levels given on soil guidelines (Ewers 1991; Pendias and Pendias 1992; USEPA 2002; CCME 2007). The variability of PTEs from different sampling sites of the agricultural soils and river water sample could be due to the direct solid and liquid waste discharge from industrial effluents and urban emissions, municipal and domestic activities, geologic deposits and agricultural practices.

The average concentrations of PTEs in the edible parts of vegetable in all farms are presented in Table 2. A statistical test of using ANOVA showed significant differences $(\mathrm{P}<0.05)$, at 95\% confidence interval, between the levels of all PTEs in vegetables obtained from the sampling sites with the exception of $\mathrm{Cr}, \mathrm{Cd}$ and $\mathrm{Ni}$ which showed no significant differences $(\mathrm{P}>0.05)$. These could be due to the differential absorption capacity of vegetables for different PTEs. Swiss chard, lettuce, cabbage and Ethiopian kale represented the edible vegetable leaves, thus above ground, and the root vegetable (carrot) and tuber vegetable (potato) represented edible underground vegetables, the latter having more contact with potential soils. $\mathrm{Mn}, \mathrm{Fe}, \mathrm{Zn}, \mathrm{Sr}, \mathrm{Ba}$ and $\mathrm{B}$ were always abundant in the vegetables studied, whereas $\mathrm{Cr}$,
$\mathrm{Cu}, \mathrm{As}, \mathrm{Cd}, \mathrm{V}$, Co and $\mathrm{Ni}$ tended to be taken up by all vegetables to the least extent (Table 2 ). $\mathrm{Zn}, \mathrm{Ba}$ and $\mathrm{B}$ concentrations were moderate in uptake by all vegetables, except $\mathrm{Ba}$ and $\mathrm{B}$ which were lower in potato. The uptake of Fe was observed to be high for all vegetables. The uptakes of Sr by Ethiopian kale and Mn by Swiss chard were high. The uptake of $\mathrm{Mn}$ was moderate in Ethiopian kale, lettuce, cabbage and carrot while there was lower accumulation by potato.

The contamination levels in other metal polluted vegetables from various regions of the world are given in Table 3. The following PTEs of this study were relatively higher than values from the other studies: $\mathrm{Cr}$, $\mathrm{Mn}, \mathrm{Cu}$ and $\mathrm{Zn}$ concentrations in Swiss chard (Itanna 1998; Fernando et al. 2012; Weldegebriel et al. 2012), Mn concentrations in both cabbage and lettuce (Itanna 1998; Song 2009; Abdul et al. 2011; Boamponsem et al. 2012; Fernando et al. 2012; Weldegebriel et al. 2012; Adeel and Riffat 2014; Lente et al. 2014), Cr, Cu, $\mathrm{Zn}$ and Ni concentrations in carrot (Boamponsem et al. 2012; Fernando et al. 2012; Adeel and Riffat 2014) and Cr, $\mathrm{Cu}$ and As concentrations in potato (Song 2009; Fernando et al. 2012; Adeel and Riffat 2014; Kifayetullah et al. 2014) (Table 3). The current results also showed higher concentrations of $\mathrm{Cr}$ and $\mathrm{Zn}$ in Ethiopian kale than the previously reported values by Weldegebriel et al. (2012). Cd, As, Ni and $\mathrm{Cr}$ were considered to be probable causes of carcinogenic risk to human beings even at low concentrations.

\section{Principal component and cluster analysis}

The Kaiser-Meyer-Olkin test value (0.71) showed that PTE datasets in vegetable samples were suitable for principal component analysis. In the Bartlett's test

Table 2 Average concentration of elements found in vegetables of all farms $(\mathrm{mg} / \mathrm{kg})$

\begin{tabular}{|c|c|c|c|c|c|c|c|}
\hline Elements & Ethiopian Kale & Lettuce & Cabbage & Swiss chard & Carrot & Potato & Guideline value $^{a}$ \\
\hline $\mathrm{Cr}$ & 1.60 & 2.57 & 1.66 & 1.96 & 2.23 & 1.43 & 2.3 \\
\hline $\mathrm{Mn}$ & 28.19 & 42.53 & 29.31 & 147.07 & 14.05 & 5.40 & $500^{b}$ \\
\hline $\mathrm{Fe}$ & 177.80 & 484.50 & 357.5 & 362.50 & 214.5 & 101.75 & 425.5 \\
\hline $\mathrm{Cu}$ & 4.80 & 11.25 & 3.26 & 11.59 & 7.33 & 5.24 & 73.3 \\
\hline $\mathrm{Zn}$ & 37.35 & 49.26 & 24.20 & 57.77 & 23.03 & 14.63 & 99.4 \\
\hline As & 0.07 & 0.10 & 0.08 & 0.12 & 0.05 & 0.03 & 0.43 \\
\hline $\mathrm{Sr}$ & 102.18 & 30.76 & 65.51 & 45.86 & 21.32 & 2.71 & - \\
\hline $\mathrm{Cd}$ & 0.08 & 0.10 & 0.04 & 0.10 & 0.05 & 0.04 & $0.2^{c}$ \\
\hline $\mathrm{Ba}$ & 46.71 & 18.07 & 31.65 & 69.17 & 18.85 & 1.97 & - \\
\hline B & 21.79 & 21.18 & 16.97 & 33.71 & 17.90 & 6.10 & - \\
\hline V & 0.40 & 0.86 & 0.60 & 0.69 & 0.39 & 0.14 & - \\
\hline Co & 0.06 & 0.29 & 0.21 & 0.34 & 0.15 & 0.13 & $50^{b}$ \\
\hline $\mathrm{Ni}$ & 0.63 & 1.82 & 1.26 & 1.47 & 1.00 & 0.55 & 67 \\
\hline
\end{tabular}

${ }^{\mathrm{a}}$ Weigert (1991), ${ }^{\mathrm{b}}$ Pendias and Pendias (1992); ${ }^{\mathrm{C}} \mathrm{FAO} / \mathrm{WHO}$ (2001) 
Table 3 Comparison of element concentrations $(\mathrm{mg} / \mathrm{kg})$ in vegetables reported in the literature

\begin{tabular}{|c|c|c|c|c|c|c|c|c|c|c|c|}
\hline Location & Vegetables & $\mathrm{Cr}$ & $M n$ & $\mathrm{Fe}$ & $\mathrm{Cu}$ & $\mathrm{Zn}$ & As & $C d$ & Co & $\mathrm{Ni}$ & References \\
\hline \multirow[t]{2}{*}{ Beijing, China } & Cabbage & 0.01 & - & - & 0.25 & 2.42 & 0.01 & 0.005 & - & 0.058 & Song (2009) \\
\hline & Potato & 0.03 & - & - & 1.03 & 3.77 & 0.01 & 0.015 & - & 0.054 & \\
\hline \multirow[t]{2}{*}{ Accra, Ghana } & Cabbage & $\mathrm{BDL}$ & 3.69 & 37.19 & 3.33 & 9.55 & - & $\mathrm{BDL}$ & 0.44 & 1.77 & Lente et al. (2014) \\
\hline & Lettuce & $\mathrm{BDL}$ & 63.96 & 108.07 & 6.26 & 10.61 & - & 0.01 & 1.07 & 2.78 & \\
\hline \multirow[t]{5}{*}{ Sao Paulo, Brazil } & S. Chard & 0.07 & - & - & - & - & - & 0.05 & 0.17 & 0.21 & Fernando et al. (2012) \\
\hline & Lettuce & 0.09 & - & - & - & - & - & 0.07 & 0.16 & 0.13 & \\
\hline & Cabbage & 0.39 & - & - & - & - & - & 0.12 & 0.51 & 0.54 & \\
\hline & Carrot & 0.09 & - & - & - & - & - & 0.03 & 0.15 & 0.11 & \\
\hline & Potato & 0.04 & - & - & - & - & - & 0.14 & 0.62 & 0.18 & \\
\hline \multirow[t]{3}{*}{ Lahore, Pakistan } & Potato & 1.60 & 17.77 & - & 4.16 & 21.77 & - & 0.21 & 53.18 & 6.04 & Adeel and Riffat (2014) \\
\hline & Cabbage & 3.06 & 17.26 & - & 4.92 & 37.76 & - & 0.27 & 47.2 & 5.05 & \\
\hline & Carrot & 1.92 & 17.45 & - & 5.34 & 19.39 & - & 0.29 & 51.2 & 5.33 & \\
\hline Swat, Pakistan & Potato & 0.11 & 0.11 & - & 0.06 & 0.07 & - & 0.09 & - & 0.06 & Kifayetullah et al. (2014) \\
\hline Quetta, Pakistan & Lettuce & - & 26.11 & 384.41 & 8.00 & 76.46 & - & 5.63 & - & 3.08 & Abdul et al. (2011) \\
\hline \multirow[t]{3}{*}{ Nagodi, Ghana } & Cabbage & - & 3.98 & 4.80 & 0.07 & 1.52 & - & $\mathrm{BDL}$ & - & - & Boamponsem et al. (2012) \\
\hline & Lettuce & - & 1.31 & 1.12 & 0.16 & 1.78 & - & $\mathrm{BDL}$ & - & - & \\
\hline & Carrot & - & 0.07 & $\mathrm{BDL}$ & 0.15 & $\mathrm{BD}$ & - & 0.08 & - & - & \\
\hline \multirow[t]{3}{*}{ Kera and Peacock, Ethiopia } & Cabbage & 1.25 & 27.00 & 123.00 & 3.17 & 31.81 & 6.56 & 0.02 & 0.10 & 0.86 & Itanna (1998) \\
\hline & Lettuce & 4.13 & 26.00 & 497.00 & 0.19 & 0.82 & 0.14 & 0.03 & 0.30 & 0.58 & \\
\hline & S. Chard & 1.55 & 52.25 & 494.00 & 7.97 & 52.10 & 10.67 & 0.06 & 0.50 & 1.50 & \\
\hline \multirow[t]{4}{*}{ Kera, Gofa and Akaki farm, Ethiopia } & S. Chard & 0.84 & 64.09 & - & 4.90 & 22.37 & - & 0.32 & 0.82 & 0.88 & Weldegebriel et al. (2012) \\
\hline & Eth. Kale & 0.90 & 19.41 & - & 6.00 & 23.45 & - & 1.02 & 1.46 & 2.46 & \\
\hline & Lettuce & 0.67 & 8.23 & - & 3.41 & 11.69 & - & 0.46 & 0.42 & 0.63 & \\
\hline & Cabbage & 0.06 & 3.82 & - & 0.99 & 3.07 & - & 0.18 & 0.05 & 0.38 & \\
\hline \multirow[t]{6}{*}{ Addis Ababa, Ethiopia } & S. Chard & 1.96 & 147.07 & 362.5 & 11.59 & 57.77 & 0.12 & 0.10 & 0.34 & 1.47 & This study mean values \\
\hline & Carrot & 2.23 & 14.05 & 214.50 & 7.33 & 23.03 & 0.05 & 0.05 & 0.15 & 1.00 & \\
\hline & Potato & 1.43 & 5.40 & 101.75 & 5.24 & 14.63 & 0.03 & 0.04 & 0.13 & 0.55 & \\
\hline & Eth. Kale & 1.60 & 28.19 & 177.80 & 4.80 & 37.35 & 0.07 & 0.08 & 0.06 & 0.63 & \\
\hline & Lettuce & 2.57 & 42.53 & 484.50 & 11.25 & 49.26 & 0.10 & 0.10 & 0.29 & 1.82 & \\
\hline & Cabbage & 1.66 & 29.31 & 357.50 & 3.26 & 24.20 & 0.08 & 0.04 & 0.21 & 1.26 & \\
\hline
\end{tabular}

-, not available; BDL, below detection limit; S. chard, Swiss chard

of sphericity, the significance level $(\sigma=0.00, \mathrm{df}=78)$ which was less than 0.05 showed that there were significant relationships among variables. The 13 variables (PTE concentrations) of the 19 vegetable samples were used as the multivariate dataset. The scree plot was used to identify the number of principle components and showed pronounced change after three eigenvalues of 7.15, 2.40 and 1.21. A biplot of the principal component analysis loading is presented in Fig. 2. The communalities of the variance with high values $(0.62-0.92)$ indicated that the extracted factors fit well with the factor solution. The first three principal components represented about $82.78 \%$ of the total variance in the vegetable datasets from eigenvalues $>1$. PC1 with $54.99 \%$ of the total data variance had a strong positive loading of $\mathrm{Fe}, \mathrm{Co}, \mathrm{Cu}, \mathrm{V}, \mathrm{Cr}$ and $\mathrm{Ni}$, and moderate loading of As and Zn. PC2 accounted for $18.48 \%$ of the total variance, with a strong positive loading of $\mathrm{Cd}$ and $\mathrm{Ba}$, and moderate loading on $\mathrm{Sr}, \mathrm{Zn}$ and $\mathrm{Mn}$ which infers the strong correlation between these PTE pairs. PC3 was associated with the $9.31 \%$ of total variance with a strong loading on B and moderate loading on Ba.

Cluster analysis was also applied to the data based on 13 variables for 19 vegetable samples. Four clusters have defined at a distance of 0.5 (Fig. 3). From the cluster analysis result, it could be concluded that there was a strong correlation between $\mathrm{Cr}, \mathrm{Fe}, \mathrm{V}, \mathrm{Cu}, \mathrm{Co}$, As and $\mathrm{Ni}$ pair which was in good agreement with $\mathrm{PC} 1(\mathrm{Fe}, \mathrm{Co}, \mathrm{Cu}, \mathrm{V}$, $\mathrm{Cr}$, As and $\mathrm{Ni}$ ), $\mathrm{Mn}, \mathrm{Ba}, \mathrm{Zn}$ and $\mathrm{Cd}$ pair showed a good agreement with $\mathrm{PC} 2(\mathrm{Cd}, \mathrm{Ba}, \mathrm{Zn}$ and $\mathrm{Mn})$, confirming these variables had a strong interrelationship (Faisal et al. 2014). 


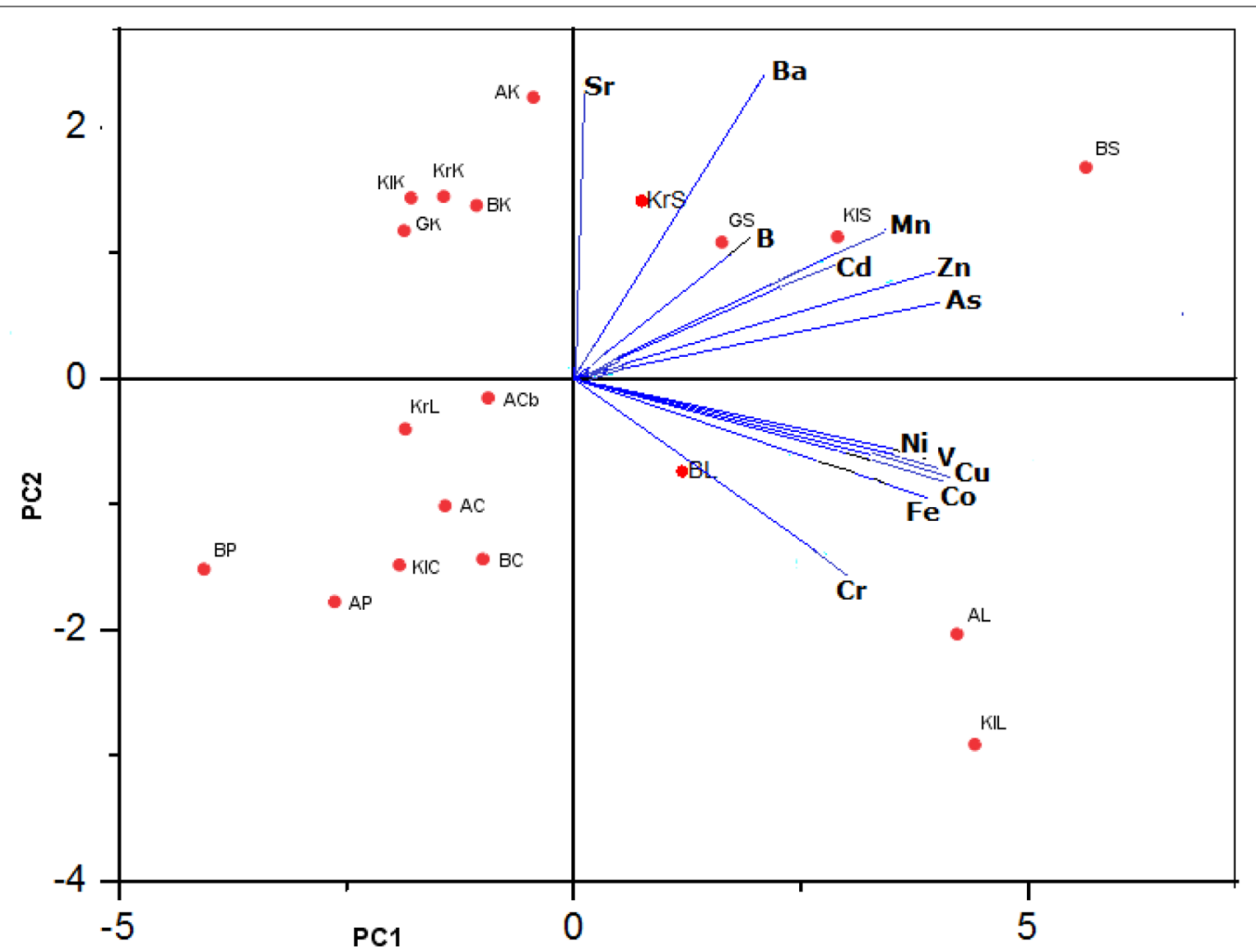

Fig. 2 Biplot of scores and loadings matrices for the first two PCs of vegetables. Where BK Burayu Ethiopian kale, KIK Kolfea Ethiopian kale, KrK Kera Ethiopian Kale, GK Gofa Ethiopian kale, BL Burayu Lettuce, KIL Kolfea Lettuce, KrL Kera Lettuce, AL Akaki Lettuce, ACb Akaki Cabbage, BS Burayu Swiss chard, KIS Kolfea Swiss chard, KrS Kera Swiss chard, GS Gofa Swiss chard, BC Burayu Carrot, KIC Kolfea Carrot, AC Akaki Carrot, BP Burayu potato and AP Akaki potato

\section{Inter-elemental correlation analysis in water, soils and vegetables}

In an attempt to understand the effect of concentrations of PTEs in the water on the soil and vegetables, Pearson correlation analysis was done. Likewise, correlation analysis was made to determine if concentrations of PTEs in the soil had an impact on the vegetables. The results demonstrated that the soil concentrations of $\mathrm{Cr}$ $(r=0.79)$ with $\mathrm{Cr}$ in lettuce, B $(r=0.98)$ with B in Kale, $\mathrm{B}(\mathrm{r}=0.94)$ with $\mathrm{B}$ in Swiss chard, $\mathrm{Ba}(\mathrm{r}=0.89)$ with $\mathrm{Ba}$ in potato, $\mathrm{Mn}(\mathrm{r}=0.99), \mathrm{Zn}(\mathrm{r}=0.99)$, As $(\mathrm{r}=0.99)$ and $\mathrm{Cd}(\mathrm{r}=0.80)$ with the contents of $\mathrm{Mn}, \mathrm{Zn}$, As and Cd in carrot, respectively showed a strong positive correlation. A strong positive relationship indicated a common source of PTE input and also implies that as the soil receives a high load of PTEs via anthropogenic sources, the accumulated PTEs are absorbed by vegetables grown on the soil and bioaccumulated into tissues. Also relatively moderate positive correlations were found between the soil concentrations of $\mathrm{Mn}(\mathrm{r}=0.67)$ and $\mathrm{Zn}(\mathrm{r}=0.62)$ with the contents of $\mathrm{Mn}$ and $\mathrm{Zn}$ in Kale, $\mathrm{Cu}(\mathrm{r}=0.54)$ with $\mathrm{Cu}$ in lettuce, $\mathrm{Cr}(\mathrm{r}=0.66)$ and $\mathrm{Co}$ $(\mathrm{r}=0.62)$ with $\mathrm{Cr}$ and Co in Swiss chard, Co $(\mathrm{r}=0.68)$ with Co carrot, respectively.

The concentrations of PTEs in the water had also a positive correlation with the levels of some PTEs that were found in the soil and vegetables. A strong positive correlations were found between soil concentrations of $\mathrm{Sr}(\mathrm{r}=0.80)$ with $\mathrm{Sr}$ in water, B $(r=0.99)$ with $\mathrm{B}$ in water, water concentrations of $\mathrm{Cr}(\mathrm{r}=0.91)$ with $\mathrm{Cr}$ in lettuce, $\mathrm{Cr}(\mathrm{r}=65)$ with $\mathrm{Cr}$ in Swiss Chard, $\mathrm{Mn}(\mathrm{r}=0.79)$ with $\mathrm{Mn}$ in potato, Fe $(r=0.65)$ with $\mathrm{Fe}$ in carrot, $\mathrm{Cu}(\mathrm{r}=0.81)$ with $\mathrm{Cu}$ in Ethiopian kale, $\mathrm{Zn}$ $(\mathrm{r}=0.83)$ with $\mathrm{Zn}$ in potato, Co $(\mathrm{r}=0.98)$ with Co in potato, $B(r=0.99)$ with $B$ in Ethiopian kale and $B$ $(r=0.98)$ with B in Swiss chard. As levels PTEs increase in the water, so do the levels rise in the soil and in the vegetables.

\section{Potential health risk assessment} Bioaccumulation factor (BCF) of PTEs from soil to vegetables From Table 4, B and Sr had higher BCF values for all types of vegetables analyzed in the study and ranging from 33.767 (potato) to 353.901 (Swiss chard), and from 


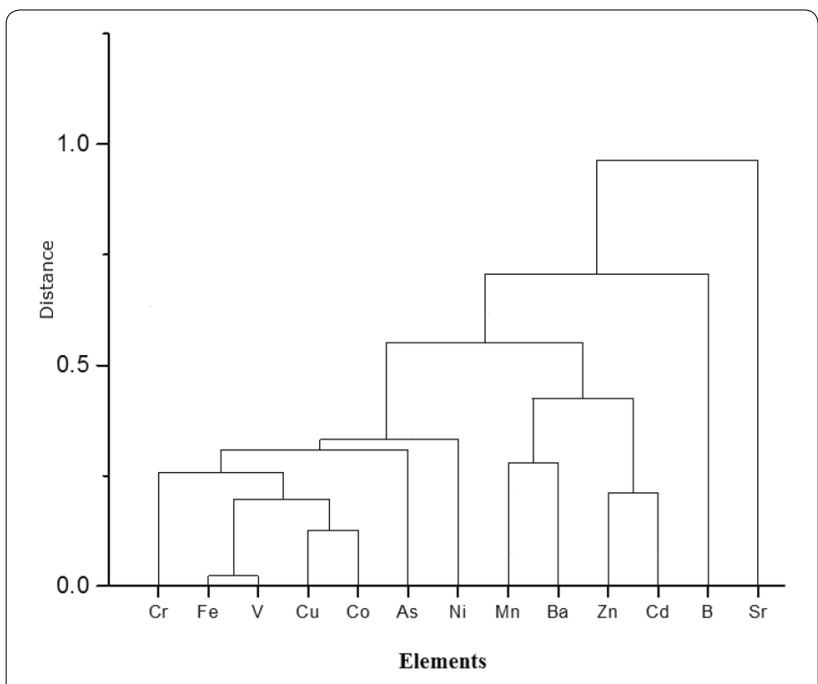

Fig. 3 Dendrogram from the cluster analysis of 13 PTEs in vegetables

0.144 (potato) to 4.398 (Ethiopian kale), respectively. The high values of exchangeable $\mathrm{B}$ and $\mathrm{Sr}$ in the vegetables may have come from the root uptake of wastewater irrigation due to the high values of B $(383.04 \mu \mathrm{g} / \mathrm{L})$ and $\mathrm{Sr}(336.75 \mu \mathrm{g} / \mathrm{L})$ in the river water used for irrigation. The values of $\mathrm{BCF}$ for $\mathrm{Cu}, \mathrm{Zn}, \mathrm{Cd}$ and $\mathrm{Ba}$ were quite high in most of the vegetables. In contrast, the BCF values for $\mathrm{V}, \mathrm{Ni}, \mathrm{Fe}, \mathrm{Mn}, \mathrm{As}, \mathrm{Cr}$ and $\mathrm{Co}$ were medium to low. Those PTEs which had high BCF values make their way to the edible part of vegetables easier than those into low BCF values (Khan 2013).

Leafy vegetables (lettuce, cabbage, Ethiopian kale and swiss chard) showed the higher BCF value than the root vegetable (carrot) and tuber vegetable (potato) for all analyzed element (Table 4). The higher growth and transpiration rates of the leaf plants may account for the higher accumulation of toxic elements in their tissues. The present result agrees with the investigation done by (Jolly et al. 2013a, b, c) in the vegetables from the agricultural land at Ruppur area of Pabna District of Bangladesh, where the bioaccumulation factors for heavy metals were significantly higher for leafy vegetables. The difference in the $\mathrm{BCF}$ values between elements could be related to bioavailability of the elements, the nature of the soil, their chemical forms, the difference in uptake capability and the growth rate of different vegetables (Cui et al. 2004; Zahara et al. 2014).

The higher growth and transpiration rates of the leafy plants may account for the higher accumulation of PTEs in their tissues (Tani and Barrington 2005). The overall mean BCF values of PTEs showed that $\mathrm{B}(120.159)>\mathrm{Sr}$ $(1.857)>\mathrm{Zn}(0.538)>\mathrm{Cd}(0.402)>\mathrm{Cu}(0.321)>\mathrm{Ba}(0.21)>\mathrm{Cr}$ $(0.055)>\mathrm{Mn}(0.042)>\mathrm{As}(0.035)>\mathrm{Ni}(0.033)>\mathrm{V}(0.011)>\mathrm{Co}$ $(0.010)>\mathrm{Fe}(0.009)$. These BCF order of most of the PTEs in vegetables agreed with the results of some previous research done (Khan et al. 2008; Jolly et al. 2013a, b, c). Although the mean values of $\mathrm{V}, \mathrm{Ni}, \mathrm{Fe}, \mathrm{Mn}, \mathrm{As}, \mathrm{Cr}$ and $\mathrm{Co}$ were high in soil, the transfer $\mathrm{BCF}$ values were very low compared to other PTEs in all vegetables, which may be related to the low concentrations of the PTEs in the vegetables. Very low BCF values for $\mathrm{V}, \mathrm{Cr}, \mathrm{Mn}, \mathrm{Fe}, \mathrm{Co}, \mathrm{Ni}$ and $\mathrm{As}$ in various vegetables were also reported by (Jolly et al. 2013a, b, c) in the agricultural land soils in the Ruppur area of Bangladesh. Therefore, these data clearly showed that, depending on the contaminant of interest, one could recommend which vegetables should be grown to reduce the risk of human exposure to soil contaminations.

\section{Daily intake of potentially toxic elements}

As presented the mean daily intake values (Table 5) for $\mathrm{Mn}$ in Ethiopian kale, lettuce, cabbage and swiss chard, $\mathrm{Cu}$ in lettuce, swiss chard and carrot, As and Fe in all the

Table 4 Bioconcentration factors (BCF) of PTEs from soil to vegetables

\begin{tabular}{lccccccc}
\hline Elements & Eth. Kale & Lettuce & Cabbage & S. chard & Carrot & Potato & Average TF \\
\hline $\mathrm{Cr}$ & 0.051 & 0.058 & 0.078 & 0.033 & 0.057 & 0.055 & 0.055 \\
$\mathrm{Mn}$ & 0.026 & 0.043 & 0.035 & 0.13 & 0.014 & 0.006 & 0.042 \\
$\mathrm{Fe}$ & 0.005 & 0.015 & 0.015 & 0.01 & 0.007 & 0.004 & 0.009 \\
$\mathrm{Cu}$ & 0.215 & 0.474 & 0.178 & 0.473 & 0.322 & 0.266 & 0.321 \\
$\mathrm{Zn}$ & 0.553 & 0.795 & 0.354 & 0.906 & 0.392 & 0.227 & 0.538 \\
$\mathrm{As}$ & 0.034 & 0.046 & 0.043 & 0.052 & 0.023 & 0.014 & 0.035 \\
$\mathrm{Sr}$ & 4.398 & 1.413 & 1.874 & 2.269 & 1.044 & 0.144 & 1.857 \\
$\mathrm{Cd}$ & 0.466 & 0.59 & 0.25 & 0.591 & 0.295 & 0.217 & 0.402 \\
$\mathrm{Ba}$ & 0.315 & 0.129 & 0.169 & 0.483 & 0.146 & 0.016 & 0.21 \\
$\mathrm{~B}$ & 162.72 & 73.911 & 37.711 & 353.901 & 58.944 & 33.767 & 120.159 \\
$\mathrm{~V}$ & 0.008 & 0.017 & 0.015 & 0.012 & 0.008 & 0.003 & 0.011 \\
$\mathrm{Co}$ & 0.003 & 0.015 & 0.014 & 0.015 & 0.007 & 0.008 & 0.01 \\
$\mathrm{Ni}$ & 0.018 & 0.051 & 0.043 & 0.04 & 0.027 & 0.017 & 0.033 \\
\hline
\end{tabular}


vegetables except potato, $\mathrm{Zn}$ in lettuce and swiss chard and $\mathrm{Ba}$ in Ethiopian kale and swiss chard in both adults and children were higher than the oral reference doses $\left(\mathrm{R}_{\mathrm{f}} \mathrm{D}\right)$ recommended by the USEPA (2002), (2005), (2008); FAO/WHO (2004) and the FAO/WHO (2004). The highest intakes of PTEs were from the consumption of lettuce and swiss chard for both adults and children. Therefore, consumption of lettuce and swiss chard, in particular, may pose severe health risks.

The estimated mean dietary intakes of $\mathrm{Zn}, \mathrm{B}$ and Sr were close to the $\mathrm{R}_{\mathrm{f}} \mathrm{D}$ for both adults and children through vegetable consumption in this study. All the estimated mean dietary intakes of $\mathrm{Co}, \mathrm{Ni}, \mathrm{V}, \mathrm{Cd}$ and $\mathrm{Cr}$ were well below the tolerable limits (Table 5 ). The degree of toxicity to human being depends on the daily intake of PTEs. PTEs such as $\mathrm{Cu}, \mathrm{Zn}, \mathrm{Fe}$ and $\mathrm{Mn}$ are nutritionally essential elements since they play an important role in biological systems. Thus, poor health can also be caused by a lack of the required elements. However, the $\mathrm{R}_{f} \mathrm{D}$ provides guidance on safe intake levels.

\section{Hazard quotient}

The hazard quotient (HQ) for selected PTEs through the consumption of Ethiopian kale, cabbage, lettuce, swiss chard, carrot and potato for both adults and children are summarized in Table 6 . The mean HQ values were greater than 1.0 (HQ $>1)$ for As and Fe in all the vegetables except potato, for $\mathrm{Mn}$ in Ethiopian kale, lettuce, cabbage and swiss chard, for $\mathrm{Cu}$ in lettuce, swiss chard and carrot, for $\mathrm{Zn}$ in lettuce and swiss chard and for $\mathrm{Ba}$ in Ethiopian kale and swiss chard for both adults and children (Table 6). Therefore, $\mathrm{Fe}, \mathrm{Mn}, \mathrm{Cu}$, $\mathrm{As}, \mathrm{Zn}$ and $\mathrm{Ba}$ contamination in vegetables would pose a health risk to consumer (Huang et al. 2008; Jolly et al. 2013a, b, c). The solubility, and hence the bioavailability and toxicity of As depend on its oxidation state. The inorganic As compounds are more toxic than organic compounds, trivalent As are more toxic than pentavalent As (Pandey and Madhuri 2014a, b). The data are limited to the health effects of $\mathrm{Fe}, \mathrm{Mn}, \mathrm{Cu}$ and $\mathrm{Ba}$ in humans, but the results from the present study showed that its average daily intake values were greater than

Table 5 Average daily intake of PTEs through consumption of vegetables ( $\mathrm{mg} / \mathrm{kg}$-day)

\begin{tabular}{|c|c|c|c|c|c|c|c|c|c|}
\hline Elements & Individual & Eth. Kale & Lettuce & Cabb. & S.Chard & Carrot & Potato & Average & $R_{f} D$ \\
\hline \multirow[t]{2}{*}{$\mathrm{Cr}$} & Adults & 0.010 & 0.016 & 0.010 & 0.012 & 0.014 & 0.009 & 0.012 & 1.500 \\
\hline & Children & 0.011 & 0.018 & 0.012 & 0.014 & 0.016 & 0.010 & 0.014 & \\
\hline \multirow[t]{2}{*}{$\mathrm{Mn}$} & Adults & 0.174 & 0.262 & 0.181 & 0.908 & 0.087 & 0.033 & 0.274 & 0.140 \\
\hline & Children & 0.200 & 0.302 & 0.208 & 1.040 & 0.100 & 0.038 & 0.315 & \\
\hline \multirow[t]{2}{*}{$\mathrm{Fe}$} & Adults & 1.100 & 2.990 & 2.210 & 2.240 & 1.320 & 0.628 & 1.750 & 0.700 \\
\hline & Children & 1.260 & 3.440 & 2.540 & 2.570 & 1.520 & 0.722 & 2.010 & \\
\hline \multirow[t]{2}{*}{$\mathrm{Cu}$} & Adults & 0.030 & 0.069 & 0.020 & 0.072 & 0.045 & 0.032 & 0.045 & 0.040 \\
\hline & Children & 0.034 & 0.080 & 0.023 & 0.082 & 0.052 & 0.037 & 0.051 & \\
\hline \multirow[t]{2}{*}{$\mathrm{Zn}$} & Adults & 0.231 & 0.304 & 0.149 & 0.357 & 0.142 & 0.090 & 0.212 & 0.300 \\
\hline & Children & 0.265 & 0.349 & 0.172 & 0.410 & 0.163 & 0.104 & 0.244 & \\
\hline \multirow[t]{2}{*}{ As } & Adults & 0.0005 & 0.0006 & 0.0005 & 0.0007 & 0.0003 & 0.0002 & 0.0005 & 0.0003 \\
\hline & Children & 0.0005 & 0.0007 & 0.0006 & 0.0008 & 0.0004 & 0.0002 & 0.0005 & \\
\hline \multirow[t]{2}{*}{$\mathrm{Sr}$} & Adults & 0.631 & 0.190 & 0.404 & 0.283 & 0.132 & 0.017 & 0.276 & 0.600 \\
\hline & Children & 0.724 & 0.218 & 0.465 & 0.325 & 0.151 & 0.019 & 0.317 & \\
\hline \multirow[t]{2}{*}{$\mathrm{Cd}$} & Adults & 0.0005 & 0.0006 & 0.0002 & 0.0006 & 0.0003 & 0.0002 & 0.0004 & 0.001 \\
\hline & Children & 0.0006 & 0.0007 & 0.0003 & 0.0007 & 0.0003 & 0.0002 & 0.0005 & \\
\hline \multirow[t]{2}{*}{$\mathrm{Ba}$} & Adults & 0.288 & 0.112 & 0.195 & 0.427 & 0.116 & 0.012 & 0.192 & 0.200 \\
\hline & Children & 0.331 & 0.128 & 0.225 & 0.491 & 0.134 & 0.014 & 0.221 & \\
\hline \multirow[t]{2}{*}{ B } & Adults & 0.134 & 0.131 & 0.105 & 0.208 & 0.110 & 0.038 & 0.121 & 0.200 \\
\hline & Children & 0.154 & 0.150 & 0.120 & 0.239 & 0.127 & 0.043 & 0.139 & \\
\hline \multirow[t]{2}{*}{ V } & Adults & 0.002 & 0.005 & 0.004 & 0.004 & 0.002 & 0.001 & 0.003 & 1.800 \\
\hline & Children & 0.003 & 0.006 & 0.004 & 0.005 & 0.003 & 0.001 & 0.004 & \\
\hline \multirow[t]{2}{*}{$\mathrm{Co}$} & Adults & 0.0003 & 0.0018 & 0.0013 & 0.0021 & 0.0009 & 0.0008 & 0.0012 & 0.043 \\
\hline & Children & 0.0004 & 0.0021 & 0.0015 & 0.0024 & 0.0011 & 0.0009 & 0.0014 & \\
\hline \multirow[t]{2}{*}{$\mathrm{Ni}$} & Adults & 0.004 & 0.011 & 0.008 & 0.009 & 0.006 & 0.003 & 0.007 & 0.020 \\
\hline & Children & 0.004 & 0.013 & 0.009 & 0.010 & 0.007 & 0.004 & 0.008 & \\
\hline
\end{tabular}

Exceedances are in italics 
Table 6 Mean HQ values of PTEs via intake of vegetables from wastewater irrigated farms

\begin{tabular}{|c|c|c|c|c|c|c|c|c|}
\hline Elements & Individual & Eth. Kale & Lettuce & Cabbage & S. chard & Carrot & Potato & Average $\mathrm{HQ}$ \\
\hline \multirow[t]{2}{*}{$\mathrm{Cr}$} & Adults & 0.007 & 0.011 & 0.007 & 0.008 & 0.009 & 0.006 & 0.008 \\
\hline & Children & 0.008 & 0.012 & 0.008 & 0.009 & 0.011 & 0.007 & 0.009 \\
\hline \multirow[t]{2}{*}{$\mathrm{Mn}$} & Adults & 1.243 & 1.875 & 1.292 & 6.483 & 0.620 & 0.238 & 1.959 \\
\hline & Children & 1.428 & 2.155 & 1.485 & 7.453 & 0.712 & 0.274 & 2.251 \\
\hline \multirow[t]{2}{*}{$\mathrm{Fe}$} & Adults & 1.568 & 4.272 & 3.152 & 3.196 & 1.891 & 0.897 & 2.496 \\
\hline & Children & 1.802 & 4.911 & 3.623 & 3.674 & 2.174 & 1.031 & 2.869 \\
\hline \multirow[t]{2}{*}{$\mathrm{Cu}$} & Adults & 0.741 & 1.736 & 0.503 & 1.787 & 1.131 & 0.808 & 1.118 \\
\hline & Children & 0.852 & 1.995 & 0.578 & 2.055 & 1.301 & 0.929 & 1.285 \\
\hline \multirow[t]{2}{*}{$\mathrm{Zn}$} & Adults & 0.768 & 1.013 & 0.498 & 1.188 & 0.474 & 0.301 & 0.707 \\
\hline & Children & 0.883 & 1.165 & 0.572 & 1.366 & 0.545 & 0.346 & 0.813 \\
\hline \multirow[t]{2}{*}{ As } & Adults & 1.522 & 2.057 & 1.646 & 2.417 & 1.029 & 0.617 & 1.548 \\
\hline & Children & 1.750 & 2.365 & 1.892 & 2.779 & 1.182 & 0.709 & 1.780 \\
\hline \multirow[t]{2}{*}{$\mathrm{Sr}$} & Adults & 1.051 & 0.316 & 0.674 & 0.472 & 0.219 & 0.028 & 0.46 \\
\hline & Children & 1.208 & 0.364 & 0.775 & 0.542 & 0.252 & 0.032 & 0.529 \\
\hline \multirow[t]{2}{*}{$\mathrm{Cd}$} & Adults & 0.494 & 0.602 & 0.247 & 0.633 & 0.288 & 0.216 & 0.413 \\
\hline & Children & 0.568 & 0.692 & 0.284 & 0.727 & 0.331 & 0.248 & 0.475 \\
\hline \multirow[t]{2}{*}{$\mathrm{Ba}$} & Adults & 1.442 & 0.558 & 0.977 & 2.134 & 0.582 & 0.061 & 0.959 \\
\hline & Children & 1.657 & 0.641 & 1.123 & 2.454 & 0.669 & 0.070 & 1.102 \\
\hline \multirow[t]{2}{*}{ B } & Adults & 0.672 & 0.654 & 0.524 & 1.040 & 0.552 & 0.188 & 0.605 \\
\hline & Children & 0.773 & 0.751 & 0.602 & 1.196 & 0.635 & 0.216 & 0.696 \\
\hline \multirow[t]{2}{*}{ V } & Adults & 0.001 & 0.003 & 0.002 & 0.002 & 0.001 & 0.0007 & 0.0017 \\
\hline & Children & 0.002 & 0.003 & 0.002 & 0.003 & 0.002 & 0.0008 & 0.0021 \\
\hline \multirow[t]{2}{*}{ Co } & Adults & 0.008 & 0.042 & 0.030 & 0.049 & 0.022 & 0.019 & 0.028 \\
\hline & Children & 0.009 & 0.048 & 0.035 & 0.056 & 0.025 & 0.021 & 0.032 \\
\hline \multirow[t]{2}{*}{$\mathrm{Ni}$} & Adults & 0.194 & 0.560 & 0.389 & 0.454 & 0.309 & 0.170 & 0.346 \\
\hline & Children & 0.223 & 0.644 & 0.447 & 0.522 & 0.355 & 0.195 & 0.398 \\
\hline
\end{tabular}

Exceedances are in italics

the $R_{\mathrm{f}} \mathrm{D}$ and thus, the HQ exceeded the safe value of 1.0. The values of $\mathrm{HQ}$ were less than 1.0 for $\mathrm{Cr}, \mathrm{Co}, \mathrm{Cd}$, $\mathrm{Ni}, \mathrm{V}, \mathrm{B}$ (except swiss chard) and Sr (except Ethiopian kale) in all tested vegetables (Table 6), thus posing little risk. The sequence of the mean $\mathrm{HQ}$ values for adults and children were $\mathrm{Fe}>\mathrm{Mn}>\mathrm{As}>\mathrm{Cu}>\mathrm{Ba}>\mathrm{Zn}>\mathrm{B}>\mathrm{Sr}>$ $\mathrm{Cd}>\mathrm{Ni}>\mathrm{Co}>\mathrm{Cr}>\mathrm{V}$ (Table 6). Huang et al. (2008) also reported the same $\mathrm{HQ}$ values trend $(\mathrm{Cd}>\mathrm{Ni}>\mathrm{Co}>\mathrm{Cr})$ in vegetables irrigated with wastewater in Kunshan, China.

\section{Hazard index}

The potential risk could be multiplied as the PTEs may result in additive or interactive effects (Wang et al. 2005; Huang et al. 2008). In the present study, the sequence of $\mathrm{HI}$ was swiss chard $>$ lettuce $>$ cabbage $>$ Ethiopian kale $>$ carrot $>$ potato for both adults and children (Table 7). The relative contributions of Ethiopia kale, lettuce, cabbage, swiss chard, carrot and potato to the aggregated health risk were $15.20 \%, 21.44 \%, 15.56 \%, 31.09 \%$, $11.16 \%$ and $5.56 \%$. The contributions of lettuce and swiss chard were higher than other vegetables. The HI values of carrot and potato indicated a low potential health risk to consumers. The relative contributions of $\mathrm{Cu}, \mathrm{Zn}, \mathrm{Sr}, \mathrm{Cd}$, $\mathrm{Ba}, \mathrm{B}$ and $\mathrm{Ni}$ to the aggregated health risk were $10.50 \%$, $6.64 \%, 4.32 \%, 3.88 \%, 9.00 \%, 5.68 \%$ and $3.26 \%$. Cr, Co and $\mathrm{V}$ contents were minimal, only $0.08 \%, 0.27 \%$ and $0.02 \%$, which may be related to the high oral reference doses of $1.5,0.043$ and $1.8 \mathrm{mg} / \mathrm{kg}$-day, respectively. Minimal contributions of $\mathrm{Cr}$ to the aggregated risks via consumption

Table 7 Average hazard index (HI) in the vegetable samples

\begin{tabular}{lccccccc}
\hline Vegetables & Ethiopian Kale & Lettuce & Cabbage & Swiss chard & Carrot & Potato & Total HI \\
\hline Hl of adults & 9.71 & 13.70 & 9.94 & 19.86 & 7.13 & 3.55 & 63.89 \\
Hl of children & 11.16 & 15.75 & 11.43 & 22.84 & 8.19 & 4.08 & 73.45 \\
\hline
\end{tabular}


of vegetables were also reported by Huang et al. (2008) and Wang et al. (2005).

\section{Conclusions}

Due to the significantly fast urban expansion and increased industrial activities, river water, soil and vegetable samples collected from five farms were contaminated by some toxic and PTEs in varying degrees. The study showed that there is a correlation between PTEs in river water, soil and vegetables, signifying the potential transfer of PTEs into the food chain. The leafy vegetables showed higher hazard index values than root and tuber vegetables for all analyzed elements. The health risk assessment of some PTEs through consumption of vegetables were low and generally assumed to be safe to the local population, but there were also other sources of PTEs exposures such as dust inhalation, dermal contact and ingestion of metal-contaminated soils which were not included in this study. These results will also provide basic information to highlight the need to introduce control measures to protect soils and thus food production from contaminants in the river water, which result from uncontrolled waste discharges from various sources.

\section{Supplementary information}

Supplementary information accompanies this paper at https://doi. org/10.1186/s40068-019-0157-x.

Additional file 1: Figure S1. Pictures of vegetable samples analyzed in the study. Figure S2. Sample digestion and analysis in the Inland Fisheries Laboratory of Ireland.

\section{Abbreviations}

PTEs: potentially toxic elements; $\mathrm{HI}$ : hazard index; $\mathrm{HQ}$ : hazard quotient; $\mathrm{BC}$ : bioaccumulation factor.

\section{Acknowledgements}

Access to the laboratory in Inland Fisheries Ireland is acknowledged and special thanks are due to Dr. Diarmiud Ryan for his expert guidance on chemical analysis.

\section{Authors' contributions}

All authors have made substantive intellectual contribution to this study in data analysis, preparation and editing of the manuscript. All authors read and approved the final manuscript.

\section{Funding}

Financial support for this project was obtained from the University of Connecticut-Addis Ababa University and the Irish Environmental Protection Agency.

\section{Availability of data and materials}

The data that support the findings of this study are available from the corresponding author upon request.

\section{Ethics approval and consent to participate} Not applicable.

\section{Consent for publication}

Not applicable.

\section{Competing interests}

The authors declare that they have no competing interests.

\section{Author details}

${ }^{1}$ College of Natural and Computational Sciences, Haramaya University, Dire Dawa, Ethiopia. ${ }^{2}$ Ethiopian Institute of Water Resources, Addis Ababa University, Addis Ababa, Ethiopia. ${ }^{3}$ School of Civil and Environmental Engineering, Addis Ababa University, Addis Ababa, Ethiopia. ${ }^{4}$ School of Biology and Environmental Sciences, University College Dublin, Dublin, Ireland.

Received: 7 June 2019 Accepted: 3 September 2019

Published online: 16 September 2019

\section{References}

Abdul KK, Zahoor AB, Safdar AK (2011) Accumulation of heavy metals by lettuce (Lactuca Sativa L.) irrigated with different levels of wastewater of Quetta City. Pakistan J Bot 443(6):2953-2960

Adeel M, Riffat N (2014) Human health risk assessment of heavy metals via consumption of contaminated vegetables collected from different irrigation sources in Lahore. Arab J Chem, Pakistan. https://doi.org/10.1016/j. arabjc.2013.07.002

Agrawal SR, Marshall F (2009) Heavy metal in vegetables collected from production and market sites of tropical urban area of India. Food Chem Toxicol 47:583-591

Ayers RS, Westcot DW (1994) Water quality for agriculture: FAO irrigation and drainage, vol 1, 29th edn. FAO, Italy

Boamponsem G, Kumi M, Debrah I (2012) Heavy metals accumulation in cabbage, lettuce and carrot irrigated with wastewater from Nagodi mining site in Ghana. Int J Sci Technol Res 1:11

CCME (Canadian Council of Ministers of the Environment) (2007) Canadian soil quality guidelines for the protection of environmental and human health. Canadian Environmental Quality Guidelines, No. 1299; ISBN 1-896997- 34-1

Chary N, Kamala C, Raj D (2008) Assessing risk of heavy metals from consuming food grown on sewage irrigated soils and food chain transfer. Ecotoxicol Environ Saf 69:513-524

China National Environmental Protection Agency (CEPA) (1995) The environmental quality standard for soils. China National Environmental Protection Agency, China (in Chinese)

Cui Y, Zhu Y, Zhai R, Huang Y, Qui Y, Liang L (2004) Transfer of metals from near a smelter in Nanning, China. Environ Int J 30:785-791

Dowdell C, Thompson M (2014) Hot block digestion of soil, sediment, waste and tissue samples for total recoverable metals MT-069-1.3

Dudka S, Chlopecka A (1990) Speciation mobility and phytoavailability of trace metals in a sewage sludge amended soil. Water Air Soil Pollut 51:153-160

Ewers U (1991) Standards, guidelines and legislative regulations concerning metals and their compounds. Metals and their compounds in the environment: occurrence, analysis and biological relevance. VCH, Weinheim, pp 458-468

Faisal B, Majumder R, Uddin M, Halim M (2014) Studies on heavy metals in industrial effluent, river and groundwater of Savar Industrial area, Bangladesh. Int J Geomat Geosci 5:182-191

FAO/WHO (2001) Codex Alimentarius Commission. Food additive and contaminants, Joint FAO/WHO Food Standards Programme, ALINORM 01/12A: 1-289

Fernando G, Anderson R, Takashi M, Nericlenes C, Solange G (2012) Heavy metals in vegetables and potential risk for human health. Sci Agric 69(1):54-60

Food and Nutritional Board (2004) Dietary Reference Intakes (DRIs). Recommended intake for individuals. National Academy of Sciences, Washington, DC

Ge K, Zhai F, Yan H (1996) The dietary and nutritional status of Chinese Population-National Nutrition Survey in 1992. People's Med Publ House Beijing 1:126-228 
Geetanjali C, Chauhan Y (2014) Risk assessment of heavy metal toxicity through contaminated vegetables from waste water irrigated area of Rewa. Int J Adv Technol Eng Sci 02:2348-7550

Hagedorn B (2008) Acid digestion of sediments, sludge and soil (EPA 3050). Applied Science, Engineering and Technology Laboratory, University of Alaska, Anchorage

Huang M, Zhou S, Sun B, Zhao Q (2008) Heavy metals in wheat grains: assessment of potential health risk for inhabitants in Kunshan, China. Sci Total Environ 405:54-61

Itanna F (1998) Metal concentrations of some vegetables irrigated with industrial liquid waste at Akaki, Ethiopia. Ethiop J Sci 21(1):133-144

Jolly Y, Akter S, Kabir J, Islam A (2013a) Health risk assessment of heavy metals via dietary intake of vegetables collected from an area selected for introducing a nuclear power plant. Res J Phys Appl Sci 2(4):043-051

Jolly Y, Akter S, Kabir J, Islam A (2013b) Health risk assessment of heavy metals via dietary intake of vegetables collected from an area selected for introducing a nuclear power plant. Res J Phys Appl Sci 2:043-051

Jolly Y, Islam A, Akbar S (2013c) Transfer of metals from soil to vegetables and possible health risk assessment. SpringerPuls 2:1-8

Kar D, Sur P, Mandal S, Saha T, Kole R (2008) Assessment of heavy metal pollution in surface water. Int J Environ Sci Technol 5(1):119-124

Khan K (2013) Heavy metals in agricultural soils and crops and their health risks in Swat District, northern Pakistan. Food Chem Toxicol 58:449-458

Khan S, Cao Q, Zheng Y, Huang Y, Zhu Y (2008) Health risks of heavy metals in contaminated soils and food crops irrigated with wastewater in Beijing, China. Environ Pollut 152:686-692

Kifayetullah K, Konglong L, Hizbullah K, Sardar K, Muhammad W, Tieyu W (2014) Heavy metals in agricultural soils and crops and their health risks in Swat District, northern Pakistan. Food Chem Toxicol 58:449-458

Lee C, Li X, Zhang G, Li J, Ding A, Wang T (2007) Heavy metals and Pb isotopic composition of aerosols in urban and suburban areas of Hong Kong and Guangzhou, South China Evidence of the long-range transport of air contaminants. Environ Pollut 41(2):432-447

Lente I, Ofosu J, Brimah A, Atiem S (2014) Heavy metal pollution of vegetable crops irrigated with wastewater in Accra, Ghana. West Afr J Appl Ecol 22(1):41-58

Lohani M, Singh S, Rupainwa D, Dhar D (2008) Seasonal variations of heavy metal contamination in river Gomti of Lucknow city region. Environ Monit Assess 147(1):253-263

Pandey G, Madhuri S (2014a) Heavy metals causing toxicity in animals and fishes. Res J Anim Vet Fish Sci 2:21-23

Pandey G, Madhuri S (2014b) Heavy metals causing toxicity in animals and fishes. Res J Anim Vet Fish Sci 2:17-23

Pendias A, Pendias H (1992) Elements of Group VIII. Trace elements in soils and plants. CRC Press, Boca Raton, pp 271-276

Song B (2009) Assessing the health risk of heavy metals in vegetables to the general population in Beijing, China. J Environ Sci 21:1702-1709

Tani F, Barrington S (2005) Zinc and copper uptake by plants under two transpiration ratios Part I. Wheat (Triticum aestivum L.). Environ Pollut 138:538-547
USEPA (U.S. Environmental Protection Agency) (1993) Reference dose (RfD): description and use in health risk assessments, Background Document 1A, Integrated risk information system (IRIS). http://www.epa.gov/iris/rfd. htm

USEPA (US Environmental Protection Agency) (1997). Exposure Factors Handbook-General Factors, EPA/600/P-95/002Fa,vol.1.Office of Research and Development, National Centre for Environmental Assessment. http:// www.epa.gov/ncea/pdfs/efh/front.pdf

USEPA (U.S. Environmental Protection Agency (1998). Integrated Risk Information System (IRIS) on Arsenic. Arsenic, inorganic (CASRN7440-38-2). Available online at: http://www.epa.gov/iris/subst/0278.htm Accessed May 2015

USEPA (U.S. Environmental Protection Agency) (2002). Region 9, Preliminary Remediation Goals. http://www.epa.Gov/region09/waste/sfund/prg

USEPA (U.S. Environmental Protection Agency (2004). Integrated Risk Information System Database (IRIS). Boron and Compounds (CASRN 7440-42-8). http://www.epa.gov/iris/subst/0410.htm. Accessed May 2015

USEPA (U.S. Environmental Protection Agency) (2005). Integrated Risk Information System Database (IRIS). Barium and Compounds (CASRN 7440-39-3). http://www.epa.gov/iris/subst/0010.htm Accessed May 2015

USEPA (U.S. Environmental Protection Agency) (2008). Provisional Peer Reviewed Toxicity Values (PPRTV) for Iron and Compounds (CASRN 7439-89- 6)

USEPA (U.S. Environmental Protection Agency) (2013). Reference dose (RfD): Description and use in health risk assessments, Background Document 1A, Integrated risk information system (IRIS). http://www.epa.gov/iris/rfd. htm

Wang X, Sato T, Xing B, Tao S (2005) Health risks of heavy metals to the general public in Tianjin, China via consumption of vegetables and fish. Sci Total Environ 350(3):28-37

Weigert P (1991) Metal loads of food of vegetable origin including mushroooms. In: Merian E (ed) Metals and their compounds in the environment: occurrence, analysis and biological relevance. VCH, Weinheim, pp 458-468

Weldegebriel T, Chandravanshi Y, Wondimu B (2012) Concentration levels of metals in vegetables grown in soils irrigated with river water in Addis Ababa, Ethiopia. Ecotoxicology Environ Saf 77(1):57-63

WHO (World Health Organization) (2004). Evaluation of certain food additives and contaminants. In: Sixty-First Report of the joint FAO/WHO Expert Committee on Food Additives. WHO Technical Series, 922, Geneva, Switzerland

Zahara B, Zafar I, Kafeel A, Abrar H, Nudrat A (2014) Vegetables as a potential source of metals and metalloids for human nutrition: a case study of Momordica charantia grown in soil irrigated with domestic sewage water in Sargodha, Pakistan. Pak J Zool 46(3):633-641

\section{Publisher's Note}

Springer Nature remains neutral with regard to jurisdictional claims in published maps and institutional affiliations. 